\title{
Návrat ke klientovi: K současnému hledání smyslu sociální práce ${ }^{1}$
} Michal Opatrný, Monika Flídrová, Anna Sýkorová

V odborném diskurzu sociální práce se dnes běžně hovoří o krizi sociální práce, která spočívá v rozmazání její identity, faktickém výkonu sociální práce nekvalifikovanými pracovníky, ztrátě společenské prestiže sociální práce, ale údajně také v oslabování sociálního státu a snižování státních výdajů na systém státem garantované sociální pomoci. Vzhledem ke specifické situaci české sociální práce a současné devalvaci pojmu krize proto v českém kontextu navrhuje Baláž v návaznosti na Jana Sokola hovořit o mizérii sociální práce. ${ }^{2} \mathrm{~V}$ této souvislosti se upozorňuje zejména na to, že ve své aktuální české podobě, zarámované systémy sociálních služeb a sociálních dávek, sociální práce sklouzla někam před počátky svého vlastního konstituování jako samostatného oboru lidské činnosti a vědy. ${ }^{3} \mathrm{~V}$ postmoderním společenském kontextu, který je charakteristický tím, že sociální rizika produkuje i nadále společnost, ale jejich řešení je na rozdíl od období moderny privatizováno, se tak nakonec uvažuje i o postupném zániku sociální práce - společenský kontext a v něm zejména materiální zajištění realizace sociální práce prostřednictvím systému sociálních služeb se pro ni stává dusící přikrývkou. ${ }^{4}$

V souvislosti s aktuálními společenskými problémy se pak uvažuje také o tom, zda nedošlo k selhání sociální práce. Nejedná se přitom o nějaké mediální či přímo bulvární téma iniciované selháním jednotlivce nebo systému, ale o polemiku sociálních pracovníků v odborném tisku. ${ }^{5}$ Zcela vážně jsou proto řešeny otázky, které by možná před několika málo lety vůbec nebyly kladeny a které se věnují identitě sociální práce. ${ }^{6}$ Snaha o její ukotvení ovšem probíhá již od minulého století. Nejprve (20.-60. léta 20. století) se v literatuře projevila snahou o obhájení profesionality sociální práce v souvislosti s definováním možných modelů pomoci. Později (od 80. let 20. století dodnes) se autoři věnují tématu zaměření a cílů sociální práce. Payne právě proto definuje tři známá pojetí oboru - (1) terapeutické (podporující seberealizaci jedinců či skupin), (2) transformační (tj. změna společnosti ve vztahu k sociálně potřebným) a (3) usilující o stabilizaci řádu -, jimiž sociální práce naplňuje své poslání směřovat k zlepšení společenských poměrů. ${ }^{7}$ Identitě sociální práce se tak dostalo i samostatného hesla v nedávno vydané (2013) Encyklopedii sociální práce. Libor Musil zde profesní identitu sociální práce chápe jako „....kolektivní sebepojetí skupiny lidí, kteří považují za žádoucí sledovat cíle a jednat přitom způsoby specifickými pro sociální práci." ${ }^{8}$

\footnotetext{
1 Tato studie je výstupem projektu specifického výzkumu 117/2013/H Pojetí kvality sociální práce v souvislosti se sebedefinováním sociálního pracovníka a jeho profese řešeného na Teologické fakultě Jihočeské univerzity v Českých Budějovicích.

2 Srov. Roman BALÁŽ, Možnosti dosahování oborových zájmů sociální práce v organizacích zaměstnávajících sociální pracovníky, Sociální práce/Sociálna práca 3/2014, s. 45-46.

3 Srov. Libor MUSIL, Tři pohledy na budoucnost sociální práce, in: Rizika sociální práce, ed. Martin SMUTEK - Friedrich W. SEIBEL - Zuzana TRUHLÁŘOVÁ, Hradec Králové: Gaudeamus, 2010, s. 11-25.

4 Srov. Oldřich CHYTIL, Důsledky modernizace pro sociální práci, Sociální práce/Sociálna práca 4/2007, s. 64-71.

5 Srov. Česká sociální práce jako obor naprosto selhala: Rozhovor Jany Kopřivové s Janem Syrovým, Sociální práce/Sociálna práca 3/2009, s. 7-9; Radka JANEBOVÁ, Selhala skutečně sociální práce jako obor?, Sociální práce/Sociálna práca 3/2010, s. 35-37.

6 Srov. Roman PORČ, Smysl v práci pracovníka terénní sociální práce s uživateli nealkoholových drog. Diplomová práce obhájená na FSS MU v Brně v r. 2013. Vedoucí práce Stanislava Ševčíková; Jana VAŠÍČKOVÁ, Interpretace role sociálního pracovníka v ženské věznici a její prožívání sociálními pracovníky. Diplomová práce obhájená na FSS MU v Brně v r. 2013. Vedoucí práce Libor Musil; @ Pojetí kvality sociální práce v souvislosti se sebedefinováním sociálního pracovníka a jeho profese. Projekt specifického výzkumu Grantové agentury Jihočeské univerzity č. 117/2013/H, Katedra etiky, psychologie a charitativní práce TF JU v Českých Budějovicích. Vedoucí řešitelského týmu Markéta Elichová (on-line), dostupné na: http://gaju.jcu.cz/grantova-agentura-ju-pro-rok-2013/TeamProjects, citováno dne 27. 2. 2015.

7 Srov. Malcom PAYNE, What is Professional Social Work?, Bristol: BASW, 2006, s. 12-20.

8 Libor MUSIL, Identita oboru/profese sociální práce, in: Encyklopedie sociální práce, ed. Oldřich MATOUŠEK, Praha: Portál, 2013 , s. 512.
} 
Stejně tak ve společenském diskurzu je sociální práce považována za obor s rozmazaným statusem a vágním smyslem. ${ }^{9}$

Otázkám po identitě sociální práce je přitom vlastní, že neřeší otázku ztráty smyslu vlastní činnosti pracovníka, se kterou bývají pomáhající profese konfrontovány. Předkládaná studie chce proto otázku smyslu a identity sociální práce uchopit jiným způsobem. Na podrobnější reflexi zdrojů krize či mizérie identity sociální práce ukazuje, že se spolu s hledáním identity sociální práce ztrácí její zaměření na klienta. Právě na míře orientace na klienta však záleží i to, do jaké míry bude či nebude mít sociální práce smysl.

\section{Krize smyslu v současném diskurzu sociální práce}

Výše naznačenou krizi či mizérii sociální práce, resp. její identity a smyslu, můžeme lépe operacionalizovat na základě současného českého odborného diskurzu. Jak bylo zmíněno již v úvodu, za př́činy ztráty smyslu sociální práce je minimálně v českém kontextu považován současný způsob financování sociální práce prostřednictvím systému sociálních služeb. Zároveň však můžeme v odborném diskurzu identifikovat i další zdroje krize smyslu. Jde zejména o reálné podmínky, ve kterých je sociální práce uskutečňována, a také o samotné vymezení sociální práce.

\subsection{Vymezení sociální práce}

Výsledky výzkumu v rámci projektu, jehož výstupem je i tato studie, ukazují, že ...chybějící viditelný a jasně ohraničený výsledek“ práce vede u některých sociálních pracovníků „...k frustraci a ztrátě jistoty chápání poslání a identity sociální práce “. ${ }^{10}$ Př́ičinou této frustrace může být právě to, co je, resp. není, za sociální práci považováno.

Česká sociální práce totiž sice disponuje velkým množstvím svých vlastních definic, zároveň je však jen část $\mathrm{z}$ nich skutečně použitelná nejen pro podporu klienta, aby dokázal dostát nárokům svého sociálního prostředí, ale také pro obhajobu práv klientů: „Práce s příčinami problémů a ovlivňování podmínek prostředí, ve kterém klienti žijí, není u nás zvykem. Důsledkem takového ustálení sociální práce může být i ,mlčení sociálních pracovníků, kteří vlastně obhajobu práv klientů ani nemusí považovat za součást poslání své profese."11 Převažující vymezení sociální práce mimo kontext ČR vycházejí naopak z problémů v interakcích mezi lidmi a z problémů podmíněných socio-kulturní růzností. ${ }^{12}$ Problém vymezení sociální práce tak fakticky prohlubuje její vlastní krizi. Je-li příčina problémů klienta primárně v jeho prostředí, ale sociální pracovník ovlivňování nárokư prostředí na klienta za sociální práci nepovažuje, vychází jeho práce s klientem nakonec vniveč. ${ }^{13}$ Česká legislativa vlastně ani nepředpokládá, že by sociální pracovníci měli také obhajovat práva svých klientů. Fakticky se v této věci vyjadřuje zřejmě jen Etický kodex sociálních pracovníků ČR, který ovšem formálně zastřešujícím profesním kodexem není. ${ }^{14} \mathrm{O}$ obhajobě práv klienta hovoří implicitně bod 2.5 tohoto kodexu,

\footnotetext{
9 Srov. Libor MUSIL, Challenges of Postmodern Institutionalisation for Education in Social Work, in: Social Work, Education and Postmodernity: Theory and Studies in Selected Czech, Slovak and Polish Issues, ed. Tatiana MATULAYOVÁ - Libor MUSIL, Liberec: TUL, 2013, s. 10.

10 Martina PAJMOVÁ - Markéta ELICHOVÁ, Role osobnosti a edukace pro kompetence sociálních pracovníků, Sociální práce/Sociálna práca 4/2014, s. 104.

11 Radka JANEBOVÁ - Marcela HUDEČKOVÁ - Romana ZAPADALOVÁ - Jana MUSILOVÁ, Příběhy sociálních pracovnic a pracovníků, kteří nemlčeli - Popis prožívaných dilemat, Sociální práce/Sociálna práca 4/2013, s. 68.

12 Srov. Roman BALÁŽ, Možnosti dosahování oborových zájmů sociální práce, s. 44.

13 Srov. Libor MUSIL, Challenges of Postmodern Institutionalisation, s. 10, pozn. 2.

$14 \mathrm{~K}$ obhajobě práv klientů v ČR se ale naopak vyjadřují ratifikované mezinárodní smlouvy (např. úmluva o právech osob se zdravotním
} 
když se v něm uvádí, že sociální pracovníci mají podněcovat změny v legislativě, upozorňovat na možnosti spravedlivějšího rozdělování společenských zdrojů a rozšiřovat možnosti ke zlepšení kvality života klientů. ${ }^{15}$

Janebová, Hudečková, Zapadalová a Musilová také upozorňují, že i taková publikace, jakou je Encyklopedie sociální práce, vlastně preferuje terapeutické pojetí sociální práce: „Pochopily jsme to tak, že řada př́spěvků $v$ encyklopedii je psána z perspektivy výhradně př́ípadové práce s klientem, namířené přednostně na adaptaci klienta na podmínky společenského prostředí.“ Autorky se proto domnívají, že vzdělávací instituce v sociální práci v ČR, ze kterých pochází většina autorů encyklopedie, ani o jiném než terapeutickém pojetí sociální práce neuvažuje, resp. že neuvažuje o iniciaci změn na straně sociálního prostředí klienta. ${ }^{16}$

Dalším ze zdrojů oslabení identity sociální práce vzhledem $\mathrm{k}$ jejímu vymezení může být i nejasnost a nejednoznačnost některých pojmů, se kterými se v sociální práci běžně operuje. Například ve 4. čísle Sociální práce z r. 2014, které se věnovalo otázce sociální spravedlnosti, můžeme najít hned několik akademických statí, které upozorňují na nejednoznačnost pojmu sociální spravedlnost. Kodex sociálních pracovníků ČR ovšem sociální spravedlnost zmiňuje vedle lidských práv jako jeden z hlavních zdrojů sociální práce. Nejpregnantněji je zřejmě celý terminologický pojem vyjádřen zde: „Zatímco v oblasti lidských práv se kodexy odkazují zejména na mezinárodní lidskoprávní dokumenty a Listinu základních práv a svobod, v oblasti sociální spravedlnosti se nemají o co opřít a spoléhají na určitou intuici a snad i samozřejmost chápání pojmu ,sociální spravedlnost'." 17 Tato samozřejmost, se kterou se celkem běžně v sociální práci předpokládá i pochopení jiných pojmů, mủže být jistě dána jak velmi praktickým zaměřením sociální práce, tak i její multidisciplinaritou. Stírání hranic vymezení jednoho a téhož pojmu v různých humanitních a společenskovědních oborech, ze kterých sociální práce čerpá, vede nakonec $\mathrm{k}$ tomu, že všichni danému pojmu přisoudí nějaký široký mezioborový význam. Ten však paradoxně nemusí mít už nic společného s původním významem pojmu v jednotlivých vědách, a tedy ani s tím, proč byl do sociální práce aplikován.

\subsection{Systém sociálních služeb}

Nezáměrně byla v ČR identita sociální práce ohrožena i zákonem 108/2006 Sb. Zákon bývá chápán jako přelomová norma, která dala sociální práci pevný legislativní i společenský rámec. Upravuje však pouze jeden ze segmentů, ve kterém je sociální práce vykonávána, tj. sociální služby. ${ }^{18}$ Zároveň je ale přes tento segment podstatná část sociální práce financována, takže pak dochází $\mathrm{k}$ tomu, že za sociální práci je považováno pouze poskytování sociálních služeb. Zákon 108/2006 Sb. tedy popsaný problém sám o sobě nezpůsobuje, protože v $\$ 1$ odst. 2 mj. výslovně uvádí, že je jím upravována sociální práce pouze tehdy, pokud je vykonávána v sociálních službách.

V průběhu roku 2014 se však tento fenomén paradoxně ještě posílil spolu s tím, že bylo od 1. ledna 2015 zavedeno financování sociálních služeb na úrovni krajů. O rozložení prostředků na jednotlivé sociální služby rozhodují krajské úřady, které by měly mít lepší povědomí než

postižením, úmluva o právech dítěte), zprávy ombudsmana, listina práv a svobod, standardy kvality sociálních služeb atp., tzn. dokumenty, které jsou také považovány za východisko sociální práce, nicméně na obecnější úrovni než profesní etické kodexy.

15 Srov. Radka JANEBOVÁ - Marcela HUDEČKOVÁ - Romana ZAPADALOVÁ - Jana MUSILOVÁ, Příběhy sociálních pracovnic a pracovníků, s. 68-69.

16 Srov. tamtéž, s. 81.

17 Roman MÍČKA, Sociální spravedlnost a lidská práva v sociální nauce církve, Sociální práce/Sociálna práca 4/2014, s. 84.

18 Srov. Anna SÝKOROVÁ - Markéta ELICHOVÁ, Kompetence sociálního pracovníka: co učí školy a co vyžadují zaměstnavatelé, Sociální práce/Sociálna práce 1/2015, podpořeno GAJU c.117/2013/H, s. 2. 
MPSV ČR o tom, jaké služby je v daném kraji, resp. jeho lokalitě, potřeba podpořit. Tato situace však zároveň více nahrává také tomu, aby byly sociální služby podporovány zcela účelově podle toho, na jakou cílovou skupinu jsou zaměřeny. Služby určené pro např. seniory nebo zdravotně postižené tak mají větší prioritu než služby pro menšiny nebo bezdomovce. Jde o čistě politický kalkul, kdy financování či nefinancování určitých služeb má přilákat či neodradit voliče stávající krajské koalice. Subsidiární financování sociálních služeb tak paradoxně může dospět $\mathrm{k}$ zcela opačným efektům než těm, které byly sledovány jeho zavedením. ${ }^{19}$

Toto a jemu podobné podřizování sociální práce sociální politice, resp. partajní sociální politice a momentálním politickým zájmům, a „vměstnání“ sociální práce do systému poskytování sociálních služeb může nakonec vést k pocitu sociálních pracovníků, že sociální práce již není tím, za co ji sami považují. Nejde už o pomoc klientovi, ale spíše o nabídku unifikovaných produktů zájemci o službu. Vztah s klientem je tím maximálně regulován, což v důsledku znamená jeho formalizaci, která vede k rutině v horším slova smyslu. Sociální pracovníci pak také např. konstatují, že více než životní situace a osoba klienta je pro ně stresující administrativní agenda a kontext, ve kterém musí pracovat. ${ }^{20}$

V důsledku popsaných problémů spojených se systémem sociálních služeb a jejich financování pak dochází k následujícímu jevu: "Jakkoli má sociální práce především individuálně etické aspirace, je zároveň vykonávána v komplexním politickém rámci moderního sociálního státu a sociální politiky. Ten však bývá motivačnímu horizontu sociálního pracovníka i možnostem jeho působení vnější, čímž se ona individuálně-etická motivace dostává do napětí vůči institučnímu okolí. “21 Ačkoliv autor uvedeného citátu toto napětí vidí kriticky a apeluje na sociální pracovníky, aby měli větší politické porozumění pro sociální stát, vzhledem k výše popsané realitě a jejím temným zákoutím, která popisuje výše odkazovaná studie Janebové a jejích spolupracovnic, je zřejmé, že sociální pracovníci jsou spíše stavěni před výzvu chránit "svoje“ oborové zájmy, resp. chránit oborové zájmy sociální práce.

\subsection{Oborové zájmy sociální práce vs. realita}

Oborové zájmy sociální práce jsou v jejím odborném diskurzu běžně a vlastně zcela samozřejmě chápány jako věc konsenzu sociálních pracovníků: „Oborovým zájmem sociální práce v organizacích je potřeba sociálních pracovníků, aby byly zajištěny takové pracovní podmínky, které jim podle nich umožní naplňovat jimi uznávané hodnoty sociální práce v organizacích, kde pracuji či pro které pracují." ${ }^{22}$

Tento přistup bývá kritizován coby projev svévole či oborové pýchy sociálních pracovníků. Kritika upozorňuje na to, že sociální práce není „... definována svým zákonným rámcem, nýbrž tím, co fakticky dělá, skoro by se chtělo říci: co si nárokuje svou faktickou péčí." ${ }^{23}$ Ve skutečnosti se zde ale přehlíží, ne-li ignoruje, že obhajoba oborových zájmů sociální práce ze strany sociálních pracovníků není dána jejich svévolí, ale současným společenským kontextem: „V postmoderní perspektivě institucionalizované sociální práce - která vychází z individualizovaných identit sociálních pracovníků, fragmentárních představ jednotlivců a jimi

\footnotetext{
19 Srov. Radka JANEBOVÁ - Marcela HUDEČKOVÁ - Romana ZAPADALOVÁ - Jana MUSILOVÁ, Příběhy sociálních pracovnic a pracovníků, s. 81.

20 Srov. Viviene E. CREE, The Changing Nature of Social Work, in: Social Work: Themes, Issues and Critical Debates, ed. Robert ADAMS -

Lena DOMINELLI - Malcolm PAYNE, Hampshire: Palgrave, 2002, s. 26.

21 Jakub JINEK, Sociální spravedlnost pro sociální práci, Sociální práce/Sociálna práca 4/2014, s. 36.

22 Roman BALÁŽ, Možnosti dosahování oborových zájmů, s. 45.

23 Jakub JINEK, Sociální spravedlnost, s. 38.
} 
konstruovaných diskurzů (o) sociální práce(i), a tedy i konstruovaných představ o oborových zájmech sociální práce - nabývá odborná svoboda jednotlivých sociálních pracovníků v organizacích podoby nezbytného předpokladu, bez kterého by nebyla institucionalizace sociální práce možná. “24

Současná situace, kdy je sociální práce vykonávána v rámci organizací, které jsou financovány skrze systém sociálních služeb, má proto na sociální práci minimálně dva paralyzující účinky:

- Jak již bylo výše popsáno (viz bod 1.2), v této situaci není v zájmu pomáhajících organizací obhajovat své klienty a požadovat změnu na straně jejich sociálního prostředí. Organizace se obhajoby svých klientů obávají, protože jsou závislé na těch, kdo o financování sociálních služeb rozhodují. ${ }^{25}$ Pokud má tato rozhodující instance jiný názor, zpravidla ten, že problém je jen na straně klienta, nechtějí tento názor organizace rozporovat právě v zájmu svého vlastního financování. Že je tím, kdo nakonec přijde nejvíc zkrátka, klient sociální práce, snad nemusí být ani dodáváno (viz bod 2).

- Zavedení systému sociálních služeb s sebou přineslo i tržní mechanismy. Ty mají přirozeně své opodstatnění; např. když si klient pečovatelské služby ve větším městě může vybrat, která organizace mu bude tuto sociální službu poskytovat. Tím je posílena role klienta a zároveň je vytvořen tlak na kvalitní poskytování sociální služby. Jiná situace však nastává v př́ípadě, kdy jsou sociální služby poskytovány na základě objednávky zadavatele (krajské úřady, magistráty a obecní úřady). O jeden balík peněz tak bojuje více organizací, které pracují se stejnými nebo podobnými klienty. Může jít např. o nízkoprahové zařízení pro děti a mládež a občanskou poradnu, tedy dvě odlišné služby, které však pracují s klienty z jedné a téže sociálně vyloučené lokality, příp. i s klienty $z$ jedné a téže rodiny. $K$ tomu se navíc přidává i konkurence mezi poskytovateli sociálních služeb a veřejnou správou. ${ }^{26}$ Negativa tržních principů mají i zde dopad na klienta. Ten však z tohoto konkurenčního boje neprofituje, protože se pro organizace stal jen prostředkem v jejich vzájemném boji o přežití.

Právě z těchto důvodů se objevuje pocit ztráty smyslu a identity sociální práce. Zároveň se proto na základě těchto důvodů jeví jako důležité, aby sociální pracovníci obhajovali oborové zájmy sociální práce. Jejich obhajoba, resp. vyjednávání sociálních pracovníků o oborových zájmech sociální práce, totiž utváři jejich identitu; definuje jejich společenskou roli a hranice vůči jiným pomáhajícím profesím. ${ }^{27}$ Tato obhajoba nemá probíhat na linii mezi sociálními pracovníky a státem, resp. samosprávou - jak by se na první pohled mohlo zdát -, nýbrž na rovině uvnitř pomáhajících organizací.

Zásadní otázkou organizací zaměstnávajících sociální pracovníky by mělo být, jak z hlediska organizace i jejích (sociálních) pracovníků vhodně vybalancovat dualitu požadované odpovědnosti k organizačním pravidlům a svobody rozhodování, resp. nezávislého uplatnění vưle sociálního pracovníka. Je možné, že sociální pracovníci považují za legitimní spíše vyjednávání (postmoderní tendence), zatímco organizace očekávají spíše prosazování (moderní tendence). V důsledku to znamená, že organizace momentálně nejsou připravené přijmout postmoderní

24 Roman BALÁŽ, Možnosti dosahování oborových zájmů, s. 52. Srov. také Libor MUSIL, Challenges of Postmodern Institutionalisation, s. 10-72.

25 Srov. Roman BALÁŽ, Možnosti dosahování oborových zájmů, s. 56.

26 Srov. Radka JANEBOVÁ - Marcela HUDEČKOVÁ - Romana ZAPADALOVÁ - Jana MUSILOVÁ, Příběhy sociálních pracovnic a pracovníků, s. 67.

27 Srov. také Libor MUSIL, Challenges of Postmodern Institutionalisation, s. 33-34. 
pojetí sociální práce, což může být dáno celkem obvyklým jevem, že jednotlivci i skupiny reagují na změny rychleji než společenské instituce a jejich organizace. ${ }^{28} \mathrm{Z}$ této situace navíc opět pramení pocit ztráty smyslu nebo i identity sociální práce u sociálních pracovníků, kteří kvůli tomu pocitují, že je více stresuje kontext jejich práce než problémy jejich klientů (viz bod 1.2). Jak je z předchozích třech bodů patrné, úvahy o rozmazání identity sociální práce a snahy o její znovunalezení či nové uchopení se do značné míry točí v sebestředném kruhu. Jinými slovy, sociální práce se zabývá víc sama sebou než tím, kým by se měla zabývat primárně, totiž svými klienty. Odpověd' na otázku, kde je identita sociální práce a jaký je její smysl, nemusí být nutně hledána přímo v sociální práci samotné. Výše bylo opakovaně připomínáno, že současná krize či mizérie sociální práce nakonec dopadá především na klienty sociálních pracovníků. Ovšem právě na ně se sociální práce zaměřuje, a zdá se proto potřebné hledat smysl sociální práce či zdroj její identity u jejích klientů.

\section{Smysl sociální práce a její klient}

S podobným pohledem na situaci sociální práce, která byla naznačena v bodě 1 , se můžeme již řadu let setkávat v odborném diskurzu o sociální práci v zahraniční literatuře. ${ }^{29}$ Podle Silvie Staub-Bernasconi lze v současné veřejné i odborné diskusi o sociální práci zaznamenat tři různé pozice, ze kterých se na ni pohlíží. Jde o východiska, ze kterých si nejen sama sociální práce, ale i jiné vědní obory, složky státu a součásti společnosti vytvářejí své vlastní teorie o sociální práci. První dvě pozice označuje Staub-Bernasconi rovnou jako extrémní:

- V rámci první pozice je promotory občanské společnosti prosazována myšlenka dobrovolné pomoci, protože pomáhat přece dokáže každý.

- Druhou pozici zastávají ti, kterým je vlastní ekonomický pohled na svět. Jimi je na sociální práci pohlíženo tak, že má naplnit určité úkoly, které si pomáhající organizace vymezila, a tak $\mathrm{v}$ důsledku přispět $\mathrm{k}$ hospodářskému růstu.

- Mezi těmito dvěma póly se pohybuje ještě třetí pohled na sociální práci, který ji vidí jako jakousi pomocnou sílu - pomocnou vzhledem k lékařům, ošetřovatelskému personálu, psychologům atp. ${ }^{30}$

Toto konstatování pochopitelně platí více v německojazyčném kontextu než v kontextu ČR, kde se s první variantou pojetí sociální práce téměř nesetkáváme, zatímco její třetí pojetí je naopak relativně rozšířené (viz bod 1). ${ }^{31}$ Bez ohledu na místní a kulturní odlišnosti však mají tyto pohledy podle Staub-Bernasconi jeden zcela zásadní nedostatek: přehlížejí potřeby člověka - tzn. klienta sociálního pracovníka. Jinak vyjádřeno, věnují se prakticky jen společenské funkci sociální práce. Druhý a třetí přístup vidí sociální práci jako opravování společnosti nebo doplňkovou činnost, která má podpořit práci těch „opravdových“ pomáhajících profesí. Co je problémem klienta a proč klient s tímto problémem bojuje, zcela vypadává ze zorných úhlů obou pojetí sociální práce. Stejně tak ovšem i v prvním př́ípadě, který Staub-Bernasconi

28 Srov. Roman BALÁŽ, Možnosti dosahování oborových zájmů, s. 51-56.

29 Srov. např. téměř deset let starý německý článek: Martin ALBERT, Die Ökonomisierung der Sozialen Arbeit, Sozial Extra 7-8/2006, s. 26-31.

30 Srov. Silvia STAUB-BERNASCONI, Soziale Arbeit als Handlungswissenschaft: systemtheoretische Grundlagen und professionelle Praxis - ein Lehrbuch, Bern; Stuttgart; Wien: Haupt, 2007, s. 12-14.

31 Srov. také Mirka NEČASOVÁ, Profesní etika, in: Metody a řízení sociální práce, ed. Oldřich MATOUŠEK, Praha: Portál, 2003 , s. 40. 
zmiňuje, protože představa, že není třeba profesionální sociální práce, může vznikat jen z nedostatku znalostí o problémech, které klienti sociálních pracovníků musí ve svém životě řešit.

Nejtvrdší kritice podrobuje Staub-Bernasconi orientaci na společenskou funkci sociální práce, která je v současné době nejvíce rozšířcená a projevuje se realizací sociální práce v rámci systému sociálních služeb. Jde tedy o kritiku systému, který neznají jen německojazyčné země, ale také ČR, jak bylo výše (bod 1) popsáno. Zde je podle Staub-Bernasconi třeba konstatovat, že východiskem uvedeného přístupu k sociální práci je "ptačí pohled“ na společnost. Proto vychází ze společensky obecného a ptá se po individuích, která mohou ohrozit stabilitu sociálních systémů. Vzniká tak „orientace na zákazníka“, kterou sociální práce přebírá z podnikového hospodářství a která ve výsledku nic neřeší, protože adresát sociální práce je viděn jako zásoba zdrojů, které je třeba vytěžit tím, že bude (znovu)učiněn schopným; bude moci opět vstoupit do tržních mechanismů ve společnosti. Z tohoto úhlu pohledu se proto také jeví jako logické, že v sociální práci existují tendence a přístupy, které vůbec neuvažují o prostředí klienta sociální práce jako o primárním zdroji jeho problémů (viz bod 1.1). "Výhodou“ tohoto př́stupu je distancování se od lidského utrpení, teorie sociální práce se jím nemusí zabývat, protože se ptá jen po tom, co s individuem udělat, aby dobře fungovaly společenské systémy, jichž je součástí. ${ }^{32} \mathrm{~V}$ rámci tvorby teorií sociální práce tak jde vlastně o systematické potlačování teorií zaměřených na potřeby adresáta sociální práce, na tzv. „zranitelného člověka“, teoriemi zaměřenými na fungování společnosti a jejích sociálních systémů. Přístup orientovaný na společenskou funkci sociální práce se navíc postupně stává součástí kultury: „Člověk je v pokušení hovořit o vzniku ,mentálního apartheidu vůči lidské nouzi` - a to na lokální, národní i nadnárodní úrovni." ${ }^{33}$

Orientace na potřeby adresáta sociální práce je tak $\mathrm{v}$ tomto kontextu denunciována coby orientace na deficity. ${ }^{34}$ Ovšem v případě, kdy se budeme podle Staub-Bernasconi orientovat právě na potřeby člověka, půjde argumentace „odspoda nahoru“ - tzn. od individuálně specifického ke společensky všeobecnému. Výchozí otázkou v takovém případě není, zda je někdo např. chudý nebo je pachatelem trestné činnosti, ale kdo je zranitelný. Teprve když je tato otázka teoreticky i prakticky zodpovězena, lze se ptát po funkci sociální práce, a to jednak vzhledem k jejím adresátům, jednak vzhledem ke společnosti a zřizovatelům či provozovatelům zařízení sociálních služeb. Podle Staub-Bernasconi je přesto možné si představit, že budou oba př́stupy (modely) komplementární, protože je třeba vidět jak mikrorovinu individua a jeho potřeb, tak i makrorovinu společnosti a jejího fungování. Teprve tehdy, když se kvůli orientaci na potřeby člověka dokáže opustit př́stup zaměřený na společenskou funkci sociální práce, bude možné ho obnovit tak, aby byla možná i komplementarita obou modelů. ${ }^{35}$

\section{Zhodnocení}

Pohled Silvie Staub-Bernasconi na současné problémy sociální práce je vlastně praktickým využitím Kantovy etiky: „Kantův univerzální kategorický imperativ v konkrétním případě znamená, že člověk má při svém jednání myslet na jiné, resp. za ně.“ Aby došlo k naplnění tohoto „... požadavku, je třeba, aby každý uvažoval z pozice nejslabšího či nejohroženějšího člena společnosti, resp. aby uvažoval za něho, či jinak, myslel na něho. “36 Proto je také možné

32 Srov. Silvia STAUB-BERNASCONI, Soziale Arbeit als Handlungswissenschaft, s. 125-129.

33 Tamtéž, s. 129.

34 Srov. tamtéž, s. 149.

35 Srov. tamtéž, s. 120-131.

36 Srov. Jindřich ŠRAJER, Sociální spravedlnost jako základní kritérium sociální práce a sociální politiky, Sociální práce/Sociálna práca 4/2014, s. 78. 
tento pohled zobecnit $\mathrm{v}$ tom smyslu, že může být platný i v českém kontextu, resp. v českých podmínkách realizace sociální práce. Pro tento kontext je však charakteristické, že se právě tomuto pohledu do značné míry brání tím, jak fungují pomáhající organizace (viz bod 1.3), které jsou financovány přes sociální služby (viz bod 1.2), což je tlačí k efektivnosti (viz bod 1.3). Na sociální práci je tak v důsledku pohližzeno od společensky všeobecného $\mathrm{k}$ individuálně specifickému (viz bod 2). Dalo by se skoro říci, že se za poslední čtvrtstoletí pohled na sociální práci prakticky nezměnil, když stále preferuje většinu před jednotlivcem.

Naštěstí pro sociální práci je tento pohled vlastní především sociální politice, resp. politice stranické, která sociální politiku na úrovni státu i krajů utváří (viz bod 1.2). Samotný odborný diskurz sociální se k tomuto pohledu staví s kritickým odstupem, ${ }^{37}$ a proto nastávají zde již zmiňované konfliktní situace. Očekávaný soubor znalostí a kompetencí sociálního pracovníka tak naštěstí stále zcela samozřejmě předpokládá, že smyslem sociální práce je pomoci klientovi. Pracovník potřebuje vedle znalostí, resp. více než znalosti i takové dovednosti, pomocí kterých se mu tento úkol podaří naplnit. ${ }^{38}$

Primární otázka sociální práce, kterou navrhuje Staub-Bernasconi, tedy kdo je zranitelný, tak konverguje se současným voláním odborného diskurzu sociální práce po tom, aby bylo zodpovědně zvažováno, zda je př́ičina problémů klienta na jeho straně, nebo na straně jeho sociálního prostředí. V kontextu psychosociální krizové pomoci a spolupráce, která je u nás zřejmě postavena více na principech sociální práce než psychologické podpory, ${ }^{39}$ se tak běžně uvažuje jak o př́ičinách zranitelnosti klienta, tak i o zdrojích pro jeho posílení ve společenském kontextu: „Zranitelnost je a vždy byla důsledkem sociálních a ekonomických rozdílů. Schopnost se zotavit proto zahrnuje společenská, kulturní, ideologická, politická - stejně jako ekonomická hlediska.“ Zranitelnost „... se snižuje, pokud v komunitě převládá dobrý ekonomický a společenský vývoj, zdravé rodinné a společenské struktury, dobré vládnutí, zavedené regionální i národní sítě, participativní komunitní struktury a řízení, př́ihodná infrastruktura služeb a hmotného prostředí..." ${ }^{40}$

Vzhledem k tomu se proto jeví jako nutné, aby samo fungování sociální práce mělo subsidiární charakter - aby sociální pracovníci mohli obhajovat odborné zájmy sociální práce (viz bod 1.3). To ale zároveň vyžaduje, aby byl podobně subsidiárně nastaven i sociálněpolitický kontext realizace sociální práce. Je-li účinnou přičinou a cílem každého společenského zřízení jednotlivý člověk, musí být logicky každá společenská činnost svou podstatou subsidiární. ${ }^{41}$ Jak samotné zacílení sociální práce na jejího klienta, tak stejné zaměření vnějšího rámce společenských struktur včetně sociální politiky teprve umožňuje nejen hledání odpovědi na otázku, kdo je zranitelný, ale také to, aby vưbec mohla být položena. Tato optika se však v současném českém kontextu př́liš „nenosí“ (viz bod 1), takže lze vlastně říci, že vyjednávání sociálních pracovníků s organizacemi a státem a jeho složkami o oborových zájmech sociální práce je svým způsobem zásadní součást diskuse o demokratických principech ve společnosti a státě. ${ }^{42}$

37 Martin SMUTEK, Sociální politika a sociální práce, in: Encyklopedie sociální práce, ed. Oldřich MATOUŠEK a kol., Praha: Portál, 2013, s. 166-167.

38 Srov. Martina PAJMOVÁ - Markéta ELICHOVÁ, Role osobnosti a edukace, s. 105-107.

39 Srov. (C) Ministerstvo vnitra, Standardy psychosociální krizové pomoci a spolupráce zaměřené na průběh a výsledek (on-line), dostupné na: www.hzscr.cz/soubor/standardy-pskps-prosinec2010-pdf.aspx, aktualizace v prosinci 2010, citováno dne 2. 3. 2015.

40 Karel ŠIMR, Neštěstí, náboženství a duchovnost, in: Psychosociální krizová spolupráce, ed. Bohumila BAŠTECKÁ, vyd. 1., Praha: Grada, 2013, s. 91.

41 Srov. Jindřich ŠRAJER, Sociální spravedlnost, s. 78.

42 K problematice vztahu sociálního státu a demokracie srov. Martin SMUTEK, Sociální stát, in: Encyklopedie sociální práce, ed. Oldřich MATOUŠEK a kol., Praha: Portál, 2013, s. 163. 


\section{Závěrem}

Vzhledem k uvedenému lze proto říci, že některé současné odborné i laické názory, které se pokouši prosazovat společensky všeobecné na úkor individuálně specifického, svým způsobem diskusi o demokratickém uspořádání společnosti naopak ohrožují. Spolu s tím, nakolik se týkají sociálních problémů a sociální práce, jdou i proti samotnému smyslu a identitě sociální práce. Odebrat rodičům právo rozhodovat o svých dětech, ${ }^{43}$ popírat výhody inkluzivního vzdělávání, ${ }^{44}$ či dokonce návrh odebírat dětem právo na život ${ }^{45}$ jen kvůli jejich zdravotnímu stavu se tak nejen jeví jako neslučitelné se samotným smyslem sociální práce, ale přímo to ohrožuje demokratické struktury ve společnosti.

Bude-li sociální práce do značné míry vymezena jen neurčitě, jako je tomu doposud (viz bod 1.1), musíme počítat i s nejasností v identitě sociálních pracovníku․.$^{46}$ Naopak posílení zacílení sociální práce na její klienty v duchu otázky, že pomoc potřebuje ten, kdo je nejvíce zranitelný, posiluje i demokratické struktury státu a společnosti. Za zmínku přitom stojí, že tato otázka je vlastně starobylým principem, kterým se řídí židovsko-křest'anské pojetí sociální pomoci. ${ }^{47}$

\section{Návrat ke klientovi: K současnému hledání smyslu sociální práce}

Abstrakł Studie pojednává o hledání smyslu a pozice sociální práce v postmoderním společenském kontextu. Aktuálně se v sociální práci hovoři o krizi a selhávání sociální práce, která spočivá v rozmazání její identity, faktickém výkonu sociální práce nekvalifikovanými pracovníky a ztrátě společenské prestiže. V současném odborném diskurzu sociální práce v ČR studie nejprve identifikuje tři okruhy, které jsou zdrojem ztráty smyslu a ohrožení identity sociální práce (vymezení sociální práce, systém sociálních služeb, reálné podmínky pro výkon sociální práce). Na základě jejich reflexe studie konstatuje, že diskurz kolem identity a smyslu sociální práce ztrácí ze zřetele klienta sociální práce. Proto stručně shrnuje pojetí sociální práce u Silvie Staub-Bernasconi, které prì vymezení sociální práce klade dưraz na otázku „Kdo je zranitelný". Na tomto základě pak studie dochází k závěru, že je nutná dalši obhajoba oborových zájmů sociální práce ve veřejném diskurzu a $\vee$ kontextu poskytovatelů sociálních služeb, která bude jako cíl sledovat nikoliv obecnou otázku identity sociální práce, nýbrž dobro jejího klienta.

Klíčová slova sociální práce, identita sociální práce, sociální politika, sociální služby, sociální stát

\section{Return to the Client: On the Contemporary Search for the Meaning of Social Work}

Abstract The study discusses the search for meaning and position of social work in postmodern social context. At present there is talk in social work of crisis and failure of social work, which consists in the blurring of its identity, the fact that social work is carried out by unqualified workers, and loss of social prestige. In the contemporary professional discourse of social work in the Czech Republic the study first identifies three areas from which the loss of meaning and threat to the identity of social work stem (definition of social work, system of social services, real conditions of carrying out social work). Based on

43 Srov. Miroslav MITLÖHNER, K právním a etickým problémům spojeným s narozením těžce malformovaného jedince, Časopis zdravotnického práva a bioetiky 1/2014, s. 48-54 (on-line), dostupné na: http://www.ilaw.cas.cz/medlawjournal/index.php/medlawjournal/ article/view/64, citováno dne 2. 3. 2015.

44 Srov. ( ) ECHO24.CZ, Další Zemanův skandál. Poslanci se bouří, Chládek chce jít na Hrad (on-line), dostupné na: http://echo24.cz/a/ wKTmz/dalsi-zemanuv-skandal-poslanci-se-bouri-chladek-chce-jit-na-hrad, aktualizace dne 15. 1. 2015, citováno dne 2. 3. 2015.

45 Srov. Miroslav MITLÖHNER, K právním a etickým problémům, s. 48-54.

46 Srov. Martina PAJMOVÁ - Markéta ELICHOVÁ, Role osobnosti a edukace, s. 108.

47 Srov. Stephanie BOHLEN, Teologie a sociální práce - podněty pro dialog, in: Teorie a práce sociální práce: Uvedení do problematiky, Praktická reflexe a aplikace, ed. Michal OPATRNÝ - Markus LEHNER, České Budějovice: Teologická fakulta Jihočeské univerzity, 2010, s. 32-33; Michal OPATRNÝ, Charitativní práce: interakce sociální práce a diakonie, in: Teorie a práce sociální práce: Uvedení do problematiky, Praktická reflexe a aplikace, ed. Michal OPATRNÝ - Markus LEHNER, České Budějovice: Teologická fakulta Jihočeské univerzity, 2010, s. 44. 
reflecting these areas the study states that the discourse concerning the identity and meaning of social work loses sight of the client of social work. That is why it briefly summarizes the conception of social work in Silvia Staub-Bernasconi, who in defining social work emphasizes the question "Who is vulnerable". On this basis the study then concludes that further defence of the professional interests of social work in public discourse and in the context of social services providers is needed, which as its goal will pursue not a general question of the identity of social work but the good of its client.

Keywords social work, identity of social work, social policy, social services, social state 